\title{
A MEMORIAL ADDRESS FOR SIR MOSES FINLEY
}

\author{
BY JACK CARGILL
}

Dr. Cargill is Associate Professor of History at Rutgers University, New Brunswick

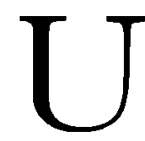

T NLIKE my distinguished predecessors today, I cannot claim the pleasure of having known Sir Moses Finley as a friend or colleague. My role is to discuss Finley as an ancient historian. I was honored to be asked to undertake this portion of the program, although I am well aware that I am only one of several persons teaching in the branches of Rutgers University who might equally well have been called upon. We are all, in a sense, his successors; I view that as both a privilege and a responsibility.

Thanks to certain fortunate circumstances, I was in fact able to have some contact with Sir Moses. Before he delivered his Mason Gross Lectures at Rutgers in April of 1972 (out of which came his book Democracy Ancient and Modern), he had delivered, earlier that same year, his Sather Lectures at the University of California, Berkeley, where I was at the time a Ph.D. student in ancient Greek history. Therefore I was privileged to be in the audience of his first lectures in America after his nearly twenty years of "exile," lectures which were to become The Ancient Economy. The attendance and the enthusiastic response given that set of lectures exceeded those for any other Sather Lecture series during my long stay in Berkeley. Later, I was one of those who recommended to the Rutgers University Press the publication of a second (expanded) edition of Democracy Ancient and Modern in I 985 -it is in print and available, and is in fact a textbook in one of my courses right now. When Finley died this past summer, I had only recently received an article offprint from him, in response to one I had sent to him. A card was attached to the offprint, reflecting Finley's last academic title, Master of Darwin College (Cambridge); where the card read "With the Compliments of the Master [,] Professor Sir Moses Finley," the words "the Master" had been crossed out, and after "Compliments" was inserted a handwritten "and thanks."

The first thing that must be said about Finley the ancient historian is that he represented the top of the profession. The great Italian scholar Arnaldo Momigliano, reviewing three of Finley's books in the New York Review 
of Books of Oct. I6, I 975, minced no words, calling him "the best living social historian of Greece and the one most prepared to face the methodological problems which social history implies"; Momigliano went on to assert that Finley had become "the most influential ancient historian of our time, equally respected and studied on both sides of what used to be called the Iron Curtain."

He was astoundingly productive. When I was asked to give this talk, I commented that I already had more books by Finley in my office (fourteen, by subsequent count) than by any other author in any field; and my - collection is by no means complete. To make sure I was aware of all of his publications, this past week I looked up the items under his name in seven different annual volumes (within the period r974-1983) of the standard bibliography of writings in fields relating to the ancient world (L'Année Philologique); I encountered 68 items (books, articles, chapters, etc.), approximately ten per year, in four languages (English, French, Italian, and German). Granted, some of these items are translations of others, some are republications of works which originally appeared elsewhere, and some are second or third entries for books listed in earlier years, added because there have been new reviews of the books which must be cited. Still, the constant republication, translation, and reviewing of Finley's works tend to show their enormous impact and influence. One of the trickiest problems in working with Finley's writings, in fact, is being sure of citing a version that is definitive, since he constantly tinkered with and revised and prepublished his articles. A piece on Sparta, for example, appeared originally in a collection of articles by several authors (mostly in French) on war-related problems in ancient Greece, published in France in I 968; it was reprinted in a collection of Finley's articles entitled The Use and Abuse of History (I 97 I), then reprinted again (under a slightly different title) in Economy and Society in Ancient Greece (1982). An article entitled "Athenian Demagogues" appeared in the journal Past and Present in I 962, then in a collection of Studies in Ancient Society which Finley edited in 1974, then again in the second-not the first-edition of Democracy Ancient and Modern ( 1985 ).

Even restricting the list to scholarly works relating to antiquity, Finley's range of expertise and interests was dazzling. Consider just some of his titles:

\footnotetext{
"Mycenaean Palace Archives and Economic History"

"Schliemann's Troy_- Ioo Years After"
} 
The World of Odysseus

"Marriage, Sale and Gift in the Homeric World"

"Myth, Memory and History"

Studies in Land and Credit in Ancient Athens

"The Athenian Empire: A Balance Sheet"

"Socrates and Athens"

"Plato and Practical Politics"

"Censorship in Classical Antiquity"

Ancient Slavery and Modern Ideology

"The Slave Trade in Antiquity . .."

"Technical Innovation and Economic Progress in the Ancient World"

The Olympic Games

The Idea of a Theatre

"The Etruscans and Early Rome"

Studies in Roman Property

"The Silent Women of Rome"

"The Emperor Diocletian"

"Christian Beginnings: . . . (sec. on) "The Jews and the Death of Jesus" "Utopianism Ancient and Modern"

Ancient Sicily to the Arab Conquest

"The Elderly in Classical Antiquity"

The Legacy of Greece

And Finley's interests, and publications, were by no means exclusively ancient-a topic to which I shall return.

Finley was a historian by training, inclination, and self-definition. Only after his education was well advanced (I cannot use a word such as "late" to describe a stage in the educational career of someone who acquired his B.A. at 15 and his M.A. at 17 !) did he focus his historical study on the ancient world, beginning with ancient law, before finding his true calling in social history. He was quite conscious of the difference in orientation and background between himself and most "classicists." In his own words:

Ancient history is unique in western history . . . in that its professional practicioners are by long tradition often men who are not in the first instance historians but men trained in language and literature who call themselves classicists ... and classical philologists, [etc.] . . . [C] lassicists by definition do not have the habit of thinking about history and historical problems other than those on which they happen to be working, do not, by and large, even read history in a serious way outside the ancient field. Their general histor- 
ical views . . . are in a sense fixed in their school-days, and those make up their basic assumptions, their subsurface generalizations, from which they proceed to classify and order events and institutions of the ancient world. ${ }^{\prime}$

The potential for conflict between such fundamentally different orientations surfaced in some literary and archaeological scholars' reactions to Finley's World of Odysseus ( I 954), to which he responded in an essay which became an appendix to the second edition:

I am a historian; my professional interest in the Iliad and Odyssey is in their usefulness as tools, as documents, for the study of Bronze Age, Dark Age and archaic Greek history. I see no need to justify in principle that way of looking at the two poems, or of any other poems that have ever been written. $^{2}$

What Finley had suggested to provoke this reaction-bold at the time, but now the consensus of scholarship-was that the Homeric poems did not present a somewhat reliable picture of the "Mycenaean" Bronze Age, but that they instead depicted essentially Dark Age society ( Ioth-gth centuries B.C.). The decipherment of Mycenaean "Linear B" writing, which had occurred just prior to the writing of his book, and which showed that the Mycenaean language was Greek, had "clinched" the historical reliability of Homer, in the minds of many classical scholars, but Finley rightly saw that the translated Linear B tablets in fact disproved the case they had been taken as proving: the complex palace economies reflected in the records on the tablets bore virtually no resemblance to the decentralized, illiterate world of Homer's warriors. A corollary, and the subject of a second appendix, was the very strong possibility, urged by Finley, that the Trojan War itself is thoroughly fictional.

Given his orientation as a historian, it follows that Finley exhibited what the editors who put together Economy and Society in Ancient Greece call "an insistence on the historical nature of human existence and thought. . . . Finley firmly rejected the ahistorical, popular notion of 'an essential sameness of institutions and problems throughout the ages. "' 3 In Democracy Ancient and Modern, Finley asserts: "The history of ideas is never just the history of ideas; it is also the history of institutions, of society itself." $4 \mathrm{He}$ attacks, for example, the application of economic categories appropriate to

' The Use and Abuse of History (New York: Viking, 1975), p. 72.

2 The World of Odysseus (New York: Penguin, 1979), p. I 42.

${ }^{3}$ Economy and Society in Ancient Greece (New York: Viking, I982), p. xiv.

${ }_{4}$ Democracy Ancient and Modern (New Brunswick: Rutgers University Press, I 985), p. I I. 
modern imperialism in an ancient Athenian context ${ }^{5}$ and he shows that the very organization and requirements of the Athenian popular assembly, its thousands of voters meeting all together in the open air, made "demagoguery" the only possible form of political leadership:

These were the conditions which faced all leaders in Athens, . . . not merely those whom some modern historians mis-call "radical democrats," but everyone, aristocrat or commoner, altruist or self-seeker, able or incompetent, who . . . "stood forward prominently to advise" the Athenians. . . . Within narrow limits, they all had to use the same techniques. . . .6

It is hardly surprising that a historically-oriented intellectual, beginning his higher education in New York in the I 930s, would have come to grips with Marxist approaches to history, and of course Finley did. He always remained respectful of much Marxist work, but his own work (as most commentators have realized) owed more to the ideas of Max Weber than to those of Marx. Momigliano reports that in Italy,

the young leftists at first greeted Finley's books with enthusiasm. They found in him that guide to ancient social problems for whom they had been vainly looking at home. But after the first expression of delight and surprise, the voices of disappointment are becoming loud. . . . His critics of course make a ludicrous mistake in taking him for a conservative, but he is certainly not a historian of revolutions.?

Finley has been described as having employed a refined version of Weber's "ideal type," following the principle that "Rather than accumulating masses of atomistic facts, the historian should concentrate on the typical experience of concrete facts that elicit a wider general whole"; this is particularly appropriate when working in the ancient field because "the occasions on which ancient historians have a reliable and useful sample of data to answer a sociological or economic question about antiquity are rare." The same commentators stress that "he is extremely sensitive to the context of the story or example and . . . [ $t]$ his sensitivity allows him to avoid examples whose circumstances would make them atypical." ${ }^{8}$ Finley's emphasis on this theme is one of the aspects I remember most vividly from his Sather Lectures, as exemplified (in the published version) by such statements as the following:

s Ibid., p. 85 .

${ }^{6}$ Ibid., p. 62.

7 Arnaldo Momigliano, in New York Review of Books ( 6 October 1975), p. 37.

${ }^{8}$ Economy and Saciety. . . , p. xviii. 
There are always exceptions, . . . but our concern must be with the prevailing ideology. One can quote Plato to "disprove" almost any general statement one tries to make about Greek society, but that is a stultifying and fundamentally wrong historical method. ${ }^{9}$

In one lecture (subsequently chapter 2), he offered a model of ancient society in which status was presented as much more relevant than any concept of class; he then proceeded to apply his model to Roman society in the time of Cicero (the late first century B.C.). The chapter's concluding paragraph states:

I chose Ciceronian Rome for special analysis precisely because that was the period when the status-based model appeared to be nearest to a break-down. It did not break, however, it bent, it adapted. . . . And if the model survived even that extraordinary period, then it was surely secure in other periods and regions. ${ }^{\mathrm{IO}}$

Although Finley devotes much discussion to the Romans, and even some to the ancient Jews, Momigliano quite correctly observes that:

only the Greeks warm Finley's heart. They are the real subject of his historical meditation . . . ${ }^{11}$

He likes them for the variety of their achievements and the complexity of their organization. . . . The Greeks are to him, as they were to the German romantics, the nearest neighbors . . . because they are our immediate predecessors in our attempts to achieve a rational organization of life. . . [And] the Greeks are not invariably inferior to us. We can still improve ourselves by taking their example into account. ${ }^{\mathrm{I2}}$

Momigliano adds the further point, which is ( $\mathrm{I}$ believe) related (though he does not make an explicit connection), that "at the bottom of his heart [Finley] cares only for the changes made by rational decision." ${ }_{13}$

A Hellenophile rationalist - that would not be a bad summary of the attitude implicit in most of Finley's writings. He comments on religion pretty well only where historical honesty seems to compel him to, and his attitude does not appear to be especially friendly. An example: "In other historical periods, religion has sometimes been a positive ideology on behalf of rights and freedom. . . . Not in Greece, however." "14 My impres-

9 The Ancient Economy (Berkeley: University of California Press, I 973), p. 38.

${ }^{10}$ Ibid., p. 6 r.

"Momigliano, p. 37.

12 Ibid., p. 36.

${ }_{13}$ Ibid., p. 37.

${ }^{14}$ Economy and Society. . . , p. 93. 
sion is that Finley looked upon the institution of democracy as a manifestation of the Greeks' rationality, and that he most admired the unusually broad democracy of classical Athens-while also lamenting the (historically explainable) low status of women and slaves there, and also while being fully cognizant that the initial establishment of such a form of government only became possible because of the existence of the Athenian

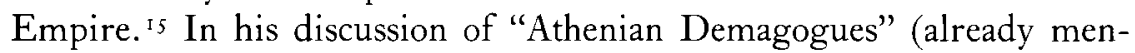
tioned), Finley praises the vision of Demosthenes and the Athenians, who "went down fighting, with an understanding of what was at stake clearer than that possessed by many critics in later ages," ${ }_{16} 6$ and he reserves his contempt for the oligarchic leaders who twice seized power late in the fifth century B.C., the real demagogues in the modern pejorative sense of "misleading the people," ${ }^{17}$ contrasting their deception and brutality very unfavorably with the restrained behavior of the restored democracy. ${ }^{18}$

Finley's admiration for the Athenian democracy comes out perhaps most strongly in discussing what is popularly regarded as its greatest misdeed, the condemnation of Socrates in 399 B.C.:

The execution of Socrates is a fact, and it is one of several such facts which reveal that Athenian democracy was not a perfect instrument. It is equally a fact, which both ancient and modern spokesmen . . . overlook, that the case of Socrates was isolated in its time. There could be no better witness to this than Plato. It was in Athens that he worked and taught, freely and safely, for most of his long life; and what he taught was hostile, down to its very roots, to much that Athenians believed and cherished. No one threatened him or stopped him. The Athenians are entitled to have their record judged whole for the two centuries in which they lived under a democracy, and not solely by their mistakes. So judged, it is an admirable record, an argument for a free society. ${ }^{19}$

The obituary in the New York Times (July I I, I 986) quotes "one admiring reviewer" as saying that Finley's essays reflected "an elegant kind of scholarly journalism," a point brought out more fully and more precisely in the obituary in the 1986 Annual Report of Jesus College, Cambridge (for which I thank Prof. McCormick):

His numerous books . . . were designed partly for the intelligent lay reader.

is Ibid., p. 92.

s6 Democracy Ancient and Modern, p. 75.

7 Ibid., p. 66.

${ }^{18}$ Ibid., p. 7 of.

${ }^{19}$ Aspects of Antiquity (New York: Viking, 1981), pp. $72 \mathrm{f}$. 
They are written vigorously and deftly, the style in which he lectured and talked. Finley was tireless in lecturing and reviewing with the object of making classical and especially Greek antiquity better understood by the general public. . . . However, Finley was no ordinary popularizer, content to disseminate received views. Even his most trifling pieces had the stamp of an original and powerful mind with fresh insights to convey.

Bernard Knox, reviewing The World of Odysseus, concludes by praising the book for being "as indispensable to the professional as it is accessible to the general reader," ${ }^{20}$ and the editors of Economy and Society comment on his "contributing to a wide range of media other than formal academic journals." ${ }^{21}$ Finley certainly justified such comments. In an article attacking elitist prejudices among educators, he says:

The mandarins should perhaps be reminded that at the University of Berlin the patron saint of twentieth-century classical scholarship, Ulrich von Wilamowitz-Moellendorf, gave two-hour public lectures every week which were events in the life of the city. "Philology," he once wrote, "is for philologists; whatever is immortal in Hellenism is for every man who wishes to come, to see and to grasp." 22

Finley was not content only to set an example of "good popularization," but he also consistently attacked "bad popularization" in reviews published in widely accessible periodicals. I shall begin with his comments on a couple of popular books with a scholarly dimension. In a review entitled "Josephus and the Bandits," in the New Statesman (December 2, I 966), even while praising Israeli scholar Yigael Yadin for his rapid publication of the excavations at Masada, "in preference to the dilatory caution, tinged with a disdain of popular presentation, common among archaeologists," Finley nonetheless says that Yadin "cannot resist making historical judgments in a way which conceals how controversial and uncertain they are." Specifically, the complaint is that Josephus' "ferocious class bias" is essentially concealed: "I do not insist that Josephus has it right, but he has something, and I insist that to wash all this out of the picture is a falsification of history. ..." Reviewing Eugene Genovese's Roll, Jordan, Roll. The World the Slaves Made, in The Spectator, Finley concludes that it is "fascinating, invaluable, often original, but at the same time a deeply flawed

${ }^{20}$ Bernard Knox, in New York Review of Books (29 June i 978), p. 8.

${ }^{21}$ Economy and Society. . . , p. xvi.

${ }^{22}$ The Use and Abuse of History, p. 2 I 2. 
book"; citing other highly laudatory reviews, he ends by asking: "Why am I out of step? What have I failed to perceive that shines so brightly and clearly to others? That is my quandary." ${ }_{23}$

These comments are rather severe, although tinged with respect as well. But for popularizing works he regarded as pure trash, Finley could be devastating. At the bottom of his fifth long column of text in a review article prompted by a popular book on Atlantis, he says: "If I have gone this far without mentioning the book I am supposed to be reviewing, that expresses my evaluation of it." ${ }_{24}$ One of Finley's most notable early reviews dealt with Will Durant's best-selling The Life of Greece, which he characterized as differing little "from other third-rate textbooks." After a series of pointed criticisms, Finley sums up:

These questions are raised from no narrow "guild" interest, nor as an attack on popular history. Quite the contrary. There exists a genuine need for popularization which will be neither vulgarization nor Philistinism. An accurate portrayal of the material and intellectual forces of Greek society in all their ramifications and interconnections can be more exciting than the cheap romanticizing of a Will Durant - and certainly more vital and socially useful. ${ }^{25}$

This interest in responsible popularization ties in closely with Finley's persistent linkage of his historical work with present-day concerns. His book titles themselves often reveal such connections: Democracy Ancient and Modern, Ancient Slavery and Modern Ideology, The Legacy of Greece. Momigliano adds that the title of the Italian translation of The Ancient Economy is L'Economia degli antichi e dei moderni- "presumably with the author's consent, ${ }^{26}$ he says. Finley concludes his above-mentioned critique of elitist educational theories by offering his own vision:

[T] he past must be deconsecrated, freed from cult, and converted into a living past; into-dare I use the word? - a relevant past. High culture must be anchored again, in new ways, to the search for, and the preservation of, values of the present and for the future. That requires abandonment of spurious, restrictive canons of eternal greatness and eternal truth: we must have the historical sense and the moral courage. . . . And we must recognize and

${ }_{23}$ The Spectator (1975): $475 \mathrm{f}$.

${ }^{24}$ New York Review of Books (22 May 1969), p. 39.

${ }_{25}$ Political Science Quarterly (1941): I 27 - I 29.

${ }_{26}$ Momigliano, p. 37. 
accept in a positive way the new reality of the student population, with its heterogeneous background and therefore its very uneven cultural endowment, and with the most diverse occupational futures. The resulting burden on education may be much greater; it remains no less essential to retain the highest quality. ${ }^{27}$

My last Finley quotations come from the concluding pages of a chapter relating to the government of ancient Athens:

I have gone into detail about some of the mechanics of Athenian democracy not from antiquarian curiosity but in order to suggest that, despite the great divide from contemporary democracy the ancient experience may not be so wholly irrelevant as modern political scientists think. . . . ${ }^{28}$

... [I]t would be . . . absurd to suggest, even to dream, that we might reinstate an Assembly of the citizens as the paramount decision-making body in a modern city or nation. . . . Public apathy and political ignorance are a fundamental fact today, beyond any possible dispute; decisions are made by political leaders, not by popular vote, which at best has only an occasional veto power after the fact. The issue is whether this state of affairs is, under modern conditions, a necessary and desirable one, or whether new forms of popular participation, in the Athenian spirit though not in the Athenian substance, . . . need to be invented. . . .29

\section{A Concluding Word}

This is a kind of Funeral Oration, but I searched the text of Pericles' famous speech, as reported by Thucydides, in vain for a concluding phrase appropriate to this particular fallen warrior. That speech's jingoistic and self-congratulatory tone does not match the expansiveness and generosity of his spirit. So I have borrowed a concluding passage from Plato, an author about whom Sir Moses himself (as we have seen) had a good many misgivings. At the end of the dialogue Phaedo, having reported the final scene of Socrates' life, the narrator sums up (Penguin translation):

Such . . . was the end of our comrade, who was, we may fairly say, of all those whom we knew in our time, the bravest and also the wisest and most upright man.

${ }_{27}$ Use and Abuse of History, p. $213 \mathrm{ff}$.

${ }^{28}$ Democracy Ancient and Modern, p. 27.

${ }^{29}$ Ibid., p. 36. 